DOI: 10.34015/2523-4552.2019.2.13

Удк 343.85

Михайлик О. Г.,

кандидат юридичних наук,

докторант кафедри управління безпеки, правоохоронної та антикорупційної діяльності ПрАТ «Вищий навчальний заклад «Міжрегіональна Академія управління персоналом»

\title{
МІЖНАРОДНІ ПІДХОДИ ДО ПРОБЛЕМИ ЗАПОБІГАННЯ НАСИЛЬСТВУ В УСТАНОВАХ ВИКОНАННЯ ПОКАРАНЬ
}

У статті проведено аналіз та узагальнення міжнародних підходів до проблеми запобігання насильству в установах виконання покарань. Зазначено, що проблема насильства в закритих інституціях властива для всіх країн світу та їхніх пенітенціарних систем. 3'ясовано, що історично й на сучасному етапі розвинені держави прагнуть об'єднати зусилля для вироблення оптимальних підходів щодо запобігання насильству в установах виконання покарань.

Ключові слова: насильство; запобігання; установа виконання покарань; міжнародні підходи; засуджені; персонал.

В статье изложены научный анализ и обобщение международных подходов к проблеме предупреждения насилия в учреждениях исполнения наказаний. Отмечено, что проблема насилия в закрытых учреждениях (которыми являются учреждения исполнения наказаний) характерна для всех стран мира и их пенитенциарных систем. Выяснено, что исторически и на современном этапе развитые государства стремятся объединить усилия в направлении выработки оптимальных подходов по предупреждению насилия в учреждениях исполнения наказаний. Констатировано, что сегодня в мире разработана международно-правовая база, состоящая из общеобязательных и рекомендательных актов, содержащих нормы, направленные на предупреждение насилия как на уровне того или иного государства в целом, так и на уровне учреждений исполнения наказаний в частности.

Ключевые слова: насилие; предупреждение; учреждение исполнения наказаний; международные подходы; осужденные; персонал.

Постановка проблеми. Варто констатувати, що, зважаючи на сучасні глобалізаційні процеси, у наукових колах утвердилася позиція, відповідно до якої вивчення міжнародних підходів та зарубіжної прак- тики 3 певного питання (проблеми) юриспруденції є своєрідною окрасою того чи іншого дослідження. Водночас, крім теоретико-пізнавального характеру, вивчення зарубіжного досвіду повинно мати і практичне 
значення, щоб удосконалити національні підходи з того чи іншого аспекту.

Тому необхідність аналізу зарубіжного досвіду запобігання насильству в установах виконання покарань (УВП) зумовлена такими чинниками: 1) визнанням на рівні міжнародно-правових актів невід'ємного права кожної людини (у тому числі засудженого) на особисту безпеку і свободу від катування та інших проявів неправомірного насильства; 2) необхідністю міжнародного співробітництва у сфері запобігання злочинам (у тому числі насильницьким); 3) науковою обгрунтованістю використання порівняльного (компаративного) методу з метою виявлення найкращих і найбільш оптимальних зарубіжних підходів до процесу запобігання насильству в УВП.

Водночас, зважаючи на вимоги до обсягу публікації рівня наукової статті, ми зупинимося на аналізі міжнародних підходів до проблеми запобігання насильству в УВП.

Аналіз останніх досліджень і публікацій. Теоретичною базою написання статті стали наукові праці вітчизняних і зарубіжних вчених, зокрема таких: Ю.М. Антоняна, М. П. Барабанова, В. С. Батиргареєвої, I. Г. Богатирьова, М. Г. Вербенського, В. О. Глушкова, В. В. Голіни, Б. М. Головкіна, О. М. Гуміна, І. М. Даньшина, С. Ф. Денисова, Т. А. Денисової, О. М. Джужі, А. І. Долгової, В. М. Дрьоміна, О. О. Дудорова, В. П. Ємельянова, А. П. Закалюка, А. Ф. Зелінського, О.Г. Кальмана, О. Г. Колба, I. М. Копотуна, О. М. Костенка, В. М. Кудрявцева, О. М. Литвака, О. М. Литвинова, В. В. Лунєєва, П. П. Михайленка, С. С. Мірошниченка, А. А. Музики, Ю. В. Орла, М. С. Пузи- рьова, А. В. Савченка, О. В. Старкова, А. Х. Степанюка, В. М. Трубникова, В. О. Тулякова, Г. А. Туманова, В. О. Човгана, В. Б. Шабанова, В. І. Шакуна, С. А. Шалгунової, О. О. Шкути, С. С. Яценка та інших дослідників.

Потановка завдання. Метою статі $€$ науковий аналіз та узагальнення міжнародних підходів до проблеми запобігання насильству в УВП.

Виклад основного матеріалу. У науково-методологічному плані в процесі аналізу проблем запобігання насильству в УВП варто підтримати позицію української дослідниці С. А. Шалгунової, що «звичайно, насильство саме по собі притаманно будь-якому суспільству, хоча самі форми прояву насильства, рівень «насичення насильством» того чи іншого суспільства будуть різними. Це залежить від систем сталих у суспільстві відносин і соціальних протиріч. Будь-яке вольове, насильницьке втручання в природний процес саморозвитку суспільства, підміна саморегулювання штучною «системою» та спроби усе переробляти за визначеним планом, доцільність якого сумнівна, неминуче призведуть до дестабілізації й непередбачуваних наслідків, нерідко до катастрофи. На уламках зруйнованого суспільства неможливо побудувати нове, тим більш якщо при цьому основним засобом $є$ насильство. Воно не відповідає поняттю творення» [1, с. 155-156].

У контексті викладеного під загальнофілософською та людинодіяльнісною категорією «творення» у проекції кримінально-виконавчої сфери ми в цій публікації розуміємо такі категорії:

- «захист інтересів особи, суспільства і держави», «виправлення i 
ресоціалізація засуджених», «запобігання вчиненню нових кримінальних правопорушень як засудженими, так i іншими особами», «запобігання тортурам та нелюдському або такому, що принижує гідність, поводженню із засудженими» (частина перша статті 1 КВК України);

- «гарантії захисту прав засуджених», «профілактика асоціальної поведінки» (частина друга статті 1 КВК України);

- принципи «невідворотності виконання і відбування покарань», «законності», «гуманізму», «поваги до прав і свобод людини», «взаємної відповідальності держави і засудженого» (стаття 5 КВК України);

- «право засуджених на гуманне ставлення до них та на повагу їх людської гідності» (абзац третій частини першої статті 8 КВК України);

- «право засуджених на особисту безпеку» (стаття 10 КВК України);

- такий елемент режиму, як «безпека засуджених і персоналу» (частина перша статті 102 КВК України);

- такі цілі оперативнорозшукової діяльності в колоніях, як «забезпечення безпеки засуджених, персоналу колоній та інших осіб», «попередження i виявлення злочинів, вчинених у колоніях, а також порушень встановленого порядку відбування покарання» (частина перша статті 104 КВК України) тощо.

У свою чергу, учинення насильства в УВП як засудженими, так і пенітенціарним персоналом, ускладнює, а то й узагалі унеможливлює досягнення вказаних соціально значущих результатів (цілей).

3 історичної точки зору варто зазначити, що в зарубіжних концепціях особиста безпека традиційно зображується як найважливіше право людини. Як наголошують ученіправники, призначення цього права полягає в забезпеченні свободи індивіда від свавільного втручання 3 боку держави та її органів, в охороні особистої сфери індивіда [2, с. 244]. Тому слушним $\epsilon$ зауваження Н. І. Баймакової, що свого часу ще англійський Білль про права 1689 р., американська Декларація незалежності 1776 р., французька Декларація прав людини і громадянина 1789 р. закріпили положення про те, що особиста безпека поряд зі свободою, власністю та опором пригніченню $\epsilon$ невід'ємним, природним правом людини [3, с. 45].

Варто зазначити, що відповідні загальновизнані світові тенденції мали вплив на розвиток теорії невід'ємних прав людини 3 позицій забезпечення безпеки і в Україні, свідченням чого $\epsilon$ конституційне положення, втілене у статті 3 Основного Закону України.

Вважається, що зародження міжнародного співробітництва 3 проблем захисту прав засуджених до позбавлення волі зумовлено, передусім, різким зростанням злочинності, у результаті чого до пенітенціарних установ направлялися все більше i більше осіб, які вчинили злочини. Тому закономірно, що збільшувалася й кількість осіб, засуджених за насильницькі злочини. Більше того, проблема посилювалася тим, що стан пенітенціарних установ не відповідав належним умовам тримання засуджених, що прирікало їх на страждання і порушувало права засуджених до позбавлення волі, у тому числі на таке право, що за сучасних умов (відповідно до статті 3 Конвенції про захист прав людини і основополож- 
них свобод (ЄКПЛ)) ототожнюється із забороною бути підданим катуванню або нелюдському чи такому, що принижує гідність, поводженню або покаранню [4].

Наприкінці XVIII ст. - на початку XIX ст. у світі відбувається широке реформування тюремних систем. Це привернуло увагу громадськості, набуло широкого резонансу, але, на жаль, засудженим до позбавлення волі це не принесло суттєвих змін. Однак реформування тюремних систем не залишилося поза увагою наукового аналізу, обговорення вчених на конференціях, круглих столах, міжнародних з'їздах. Хоча, як зазначають сучасні вчені М. С. Пузирьов та 0. О. Шкута, відповідні міжнародні форуми середини XIX ст. проходили 3 ініціативи приватних осіб і мали благодійні цілі [5, с. 8].

Згодом ситуація змінилася на краще, і в 1872 р. в Лондоні відбувся міжнародний тюремний конгрес, який започаткував міжнародне співробітництво в пенітенціарній сфері. Усього таких конгресів відбулося 12. Усі вони були не приватними зібраннями, а проводилися на урядовому рівні, а тому мали міжнародний характер [6, с. 21].

Важливо наголосити, що саме 3 проведенням тюремних конгресів, по суті, з'явилися перші міжнародні норми поводження із засудженими. Це $\epsilon$ підставою говорити про створення інституту захисту прав засуджених в умовах несвободи, у тому числі від неправомірного насильства. Варто також звернути увагу, що США першими у $1870 \mathrm{p}$. розробили проект Правил поводження із засудженими. Цей документ складався із 41 розділу, де містилися єдині принципи і форми роботи із засудженими. I хоча цей проект у 1872 р. на конгресі в Лондоні не був прийнятий, його ідеї закладено в роботу інших конгресів.

Історики тюремної системи вважають, що вказаний документ - це перша спроба створити загальні стандартні міжнародні правила поводження із засудженими, які грунтувалися б на досягненнях пенітенціарної науки та узагальненнях передової світової практики. Крім того, цей документ вплинув і на створення пенітенціарного законодавства, і на тюремну практику роботи із засудженими та ув'язненими. Відповідно він мав вплив і на роботу наступних міжнародних тюремних конгресів. Зазначимо, що на сьогодні сучасними прообразами загаданого історичного документа $\epsilon$ Мінімальні стандартні правила Організації Об'єднаних Націй $(\mathrm{OOH})$ стосовно поводження 3 ув'язненими (Правила Нельсона Мандели) (на світовому рівні) [7] та Європейські пенітенціарні правила (на європейському рівні) [8]. Зокрема, у зазначених міжнародно-правових актах відображені визнані світовою спільною підходи до такого варіанту організації пенітенціарного процесу, за якого забезпечується свобода засуджених від катування та мінімізація актів неправомірного насильства під час відбування покарання.

Варто відзначити, що США в питаннях захисту прав засуджених до позбавлення волі були родоначальниками. Саме в цій країні у 1926 р. розпочато роботу зі створення єдиного документа, який містив би в собі всі питання щодо поводження із засудженими, у тому числі визначав той мінімум прав осіб, які позбавлені волі за постановою судових властей. У 1929 р. робота над таким документом завершено, проте його прийнят- 
тя відбулося тільки в 1934 р. на засіданні Ліги Націй. Він проіснував до 1949 р. Це був перший міжнародний проект Мінімальних стандартних правил поводження із засудженими.

Надалі захист прав засуджених до позбавлення волі від неправомірного насильства пов'язаний із виникненням та функціонуванням ООН, яка однією зі своїх цілей проголосила міжнародне співробітництво з метою розвитку загальної поваги і дотримання прав людини і основних свобод для всіх, незалежно від національності, раси, статі, мови і релігії, незалежно від того, в яких умовах людина перебуває: в умовах волі чи позбавлення такої.

Тому закономірно, що на першому засіданні ООН у 1949 р. було вирішено розробити новий варіант Міжнародних правил поводження із засудженими 3 урахуванням нових умов. Цей документ пройшов міжнародну експертизу і в 1955 р. на першому Конгресі ОOH успішно прийнятий під назвою «Мінімальні стандартні правила поводження із засудженими».

На всіх наступних Конгресах ООН приймалися резолюції щодо реалізації Мінімальних стандартних правил поводження із засудженими в національних законодавствах держав-делегатів та їх удосконалення. Загалом прийняті першим Конгресом ООН Мінімальні стандартні правила поводження із засудженими закріпили мінімум прав засуджених, які зобов'язана поважати і дотримуватися адміністрація пенітенціарних установ. До таких прав належить i право засуджених на особисту безпеку та свободу від неправомірного насильства під час відбування покарання.
Також важливо зазначити, що сучасні міжнародні підходи до проблеми запобігання насильству в УВП випливають із низки міжнародноправових актів, які мають загальнообов'язковий характер для держав, що їх ратифікували (зокрема й України).

Здійснений нами аналіз за цим напрямом засвідчив, що міжнародноправові аспекти запобігання насильству в УВП виходять, насамперед, із міжнародних актів з питань захисту прав людини (незалежно від їі правового становища) та грунтуються на наступних засадничих положеннях.

По-перше, вступ України до Ради Європи (РЄ) 9 листопада 1995 р. Варто наголосити, що основною статутною умовою для вступу країн до $\mathrm{P} \in$ в визнання державою-кандидатом принципу верховенства права, їі зобов'язання забезпечити права та основні свободи людини всім особам, які знаходяться під їі юрисдикцією. Вступ країни до РЄ свідчить про ї̈ демократичний вибір, спрямованість на захист прав людини та зміцнення демократичних інститутів. Тому цілком логічно, що зазначені вимоги дотримано i в новій Конституції України 1996 р., а саме у статті 8 0сновного Закону закріплено принцип верховенства права.

По-друге, у низці норм національного законодавства закріплено такі концептуальні положення:

- чинні міжнародні договори, згода на обов'язковість яких надана Верховною Радою України, є частиною національного законодавства України (стаття 9 Конституції України) [9];

- чинні міжнародні договори України, згода на обов'язковість яких надана Верховною Радою України, є 
частиною національного законодавства і застосовуються в порядку, передбаченому для норм національного законодавства. Якщо міжнародним договором України, який набрав чинності в установленому порядку, визначено інші правила, ніж ті, що передбачені у відповідному акті законодавства України, то застосовуються правила міжнародного договору (стаття 19 Закону України «Про міжнародні договори України») [10];

- кримінально-виконавче законодавство України складається 3 КВК України, інших актів законодавства, а також чинних міжнародних договорів, згода на обов'язковість яких надана Верховною Радою України (стаття 2 КВК України) [11].

По-третє, дія в Україні Закону «Про виконання рішень та застосування практики Європейського суду 3 прав людини», який регулює відносини, що виникають у зв'язку 3 обов'язком держави виконати piшення Європейського суду 3 прав людини у справах проти України; 3 необхідністю усунення причин порушення Україною ЄКПЛ і протоколів до неї; з упровадженням в українське судочинство та адміністративну практику європейських стандартів прав людини; зі створенням передумов для зменшення кількості позовів до Європейського суду з прав людини проти України [12].
Висновки. Отже, на підставі викладеного доходимо таких загальних висновків щодо міжнародних підходів до проблеми запобігання насильству в УВП:

- проблема насильства в закритих інституціях (якими є УВП) властива для всіх країн світу та їхніх пенітенціарних систем;

- історично й на сучасному етапі розвинені держави прагнуть об'єднати зусилля до вироблення оптимальних підходів щодо запобігання насильству в УВП;

- на сьогодні у світі розроблена міжнародно-правова база, що складається як із загальнообов'язкових (Miжнародний пакт про громадянські i політичні права; Конвенція проти катувань та інших жорстоких, нелюдських або таких, що принижують гідність, видів поводження і покарання; Європейська конвенція про запобігання катуванням чи нелюдському або такому, що принижує гідність, поводженню чи покаранню; ЄКПЛ та ін.), так і рекомендаційних (Мінімальні стандартні правила ООН стосовно поводження з ув'язненими (Правила Нельсона Мандели), Європейські пенітенціарні правила, Кодекс поведінки посадових осіб із підтримання правопорядку та ін.) актів, що містять норми, спрямовані на запобігання насильству на рівні окремої держави загалом та на рівні УВП зокрема.

\section{Список використаних джерел}

1. Шалгунова С. А. Особа насильницького злочинця: монографія. 2-е вид., доп. і перероб. Дніпропетровськ : Ліра ЛТД, 2011. 548 с.

2. Права человека. История, теория и практика: учеб. пособ. / отв. ред. Б. Л. Назаров. Москва : Русслит, 1995. 304 с.

3. Баймакова Н. И. Деликты создания опасности. Российская юстиция. 2009. № 2. С. 45-46.

4. Конвенція про захист прав людини і основоположних свобод: прийнято Радою Європи 04.11.1950р., ратифіковано Законом України № 475/97-ВР від 
17.07.1997 p. URL: http://zakon2.rada.gov.ua/laws/show/995_004 (дата звернення: 31.07.2019).

5. Пузирьов М.С., Шкута О. О. Перші міжнародні пенітенціарні конгреси (1846, 1847, 1857 рр.) як історико-правовий вимір порівняльних кримінальновиконавчих досліджень. Науковий вісник Міжнародного гуманітарного університету. Серія: Юриспруденція. 2016. Вип. 19. С. 106-108.

6. Радов Г. Пенітенціарна ідея: Думки на тему. Київ : МП «Леся», 1997. 288 с.

7. Минимальные стандартные правила Организации Объединенных Наций в отношении обращения с заключенными (Правила Нельсона Манделы): резолюция Генеральной Ассамблеи 70/175 от 17.12.2015. URL: https://www.unodc.org/ documents/justice-and-prison-reform/Nelson_Mandela_Rules-R-ebook.pdf (дата звернення: 31.07.2019).

8. Європейські пенітенціарні правила (Рекомендація № R (2006)2 Комітету Міністрів держав-учасниць): прийнято Комітетом Міністрів 11.01.2006 p. URL: http://zakon4.rada.gov.ua/laws/show/994_032 (дата звернення: 31.07.2019).

9. Конституція України: Закон України від 28.06.1996 р. № 254к/96-ВР. Відомості Верховної Ради України. 1996. № 30. Ст. 141.

10. Про міжнародні договори України: Закон України від 29.06.2004 р. № 1906IV. Відомості Верховної Ради України. 2004. № 50. Ст. 540.

11. Кримінально-виконавчий кодекс України: Закон України від 11.07.2003 р. № 1129-IV. Відомості Верховної Ради України. 2004. № 3-4. Ст. 21.

12. Про виконання рішень та застосування практики Європейського суду 3 прав людини: Закон України від 23.02.2006 p. № 3477-IV. Відомості Верховної Ради України. 2006. № 30. Ст. 260.

\section{References}

1. Shalgunova, S. A. (2011). Osoba nasilnickogo zlochincya: monografiya. 2-e vid., dop. i pererob. Dnipropetrovsk : Lira LTD [in Ukrainian].

2. Nazarov, B. L. (Red.). (1995). Prava cheloveka. Istoriya, teoriya i praktika: ucheb. posob. Moskva : Russlit [in Russian].

3. Bajmakova, N. I. (2019). Delikty sozdaniya opasnosti. Rossijskaya yusticiya, 2, 45-46 [in Russian].

4. Konvenciya pro zahist prav lyudini i osnovopolozhnih svobod: prijnyato Radoyu Yevropi (1950), ratifikovano Zakonom Ukrayini № 475/97-VR vid 17.07.1997. URL: http://zakon2.rada.gov.ua/laws/show/995_004 (accessed: 31.07.2019) [in Ukrainian].

5. Puzirov, M.S., Shkuta, O. O. (2016). Pershi mizhnarodni penitenciarni kongresi (1846, 1847, 1857 rr.) yak istoriko-pravovij vimir porivnyalnih kriminalno-vikonavchih doslidzhen. Naukovij visnik Mizhnarodnogo gumanitarnogo universitetu. Seriya: Yurisprudenciya, 19, 106-108 [in Ukrainian].

6. Radov, G. (1997). Penitenciarna ideya: Dumki na temu. Kiyiv: Lesya [in Ukrainian].

7. Minimalnye standartnye pravila Organizacii Obedinennyh Nacij v otnoshenii obrasheniya s zaklyuchennymi (Pravila Nelsona Mandely): rezolyuciya Generalnoj Assamblei $70 / 175$ ot 17.12.2015. URL: https://www.unodc.org/documents/justice-and-prisonreform/Nelson_Mandela_Rules-R-ebook.pdf (accessed: 31.07.2019) [in Ukrainian].

8. Yevropejski penitenciarni pravila (Rekomendaciya № R (2006)2 Komitetu Ministriv derzhav-uchasnic): prijnyato Komitetom Ministriv 11.01.2006 r. URL: http://zakon4.rada.gov.ua/laws/show/994_032 (accessed: 31.07.2019) [in Ukrainian].

9. Konstituciya Ukrayini (1996). № 254k/96-VR. Vidomosti Verhovnoyi Radi Ukrayini, 30, 141 [in Ukrainian]. 
10. Pro mizhnarodni dogovori Ukrayini: Zakon Ukrayini (2004). № 1906-IV. Vidomosti Verhovnoyi Radi Ukrayini, 50, 540 [in Ukrainian].

11. Kriminalno-vikonavchij kodeks Ukrayini: Zakon Ukrayini vid 11.07.2003 r. № 1129IV. Vidomosti Verhovnoyi Radi Ukrayini. 2004, 3-4, 21 [in Ukrainian].

12. Pro vikonannya rishen ta zastosuvannya praktiki Yevropejskogo sudu z prav lyudini: Zakon Ukrayini vid 23.02.2006 r. № 3477-IV. Vidomosti Verhovnoyi Radi Ukrayini. 2006, 30. 260 [in Ukrainian].

O. Mykhailyk, PhD in Law, candidate for Doctor of Law degree at Security Management, Law Enforcement and Anti-Corruption Activities Chair of «Higher Educational Institution «Interregional Academy of Personnel Management»

\section{International approaches to the problem of violence prevention in penal institutions}

The article presents the scientific analysis and generalization of international approaches to the problem of violence prevention in penal institutions. The author carried out basic provisions on which international legal aspects of violence prevention in penal institutions are based.

It is noted that the problem of violence in closed institutions (which are penal institutions) is common to all countries of the world and their penitentiary systems. It has been found that, historically and at the present stage, developed countries have sought to work together to develop optimal approaches to preventing violence in penal institutions.

It is stated that today in the world an international legal framework has been developed, consisting of both mandatory and advisory acts, which contain norms aimed at preventing violence both at the level of one or another country as a whole and at the level of penal institutions in particular. Mandatory acts include the International Covenant on Civil and Political Rights; The Convention against Torture and Other Cruel, Inhuman or Degrading Treatment or Punishment; the European Convention for the Prevention of Torture and Inhuman or Degrading Treatment or Punishment; the Convention for the Protection of Human Rights and Fundamental Freedoms, etc. Recommendations include the United Nations Standard Minimum Rules for the Treatment of Prisoners (Nelson Mandela Rules), the European Prison Rules, the Code of Conduct for Law Enforcement Officials, etc.

Keywords: violence; prevention; penal institution; international approaches; convicts; personnel.

Надійшла до редакції 02.08.2019 